\title{
National wealth and private poverty through civil law? a review of the book "The Code of Capital" by Katharina Pistor
}

\section{Hans-Bernd Schäfer ${ }^{1}$ (D)}

Accepted: 16 September 2021 / Published online: 7 October 2021

(c) The Author(s) 2021

\section{Introduction}

Katharina Pistor, who studied law and earned her doctorate in Germany, is a professor of comparative law at Columbia University in New York. She is an internationally renowned scholar who uses economic and social sciences as well as empirical methods for her jurisprudential and comparative legal research. The central thesis of her book is that private law, in conjunction with its increasingly global outreach, serves the interests of the rich and enables "rule by law" (p. 205) rather than a "rule of the law". The rules of contract law, corporate law, insolvency law, property law and private international law are of particular importance in this regard. According to the author, these areas of the law shape or "encode" the domination of resources and capital in ways that increase wealth and inequality. The book seeks to understand, from a jurisprudential perspective, disruptive economic developments such as the Lehman crisis, rising inequality and the lagging of wages behind general economic development in the US and Western industrialised economies, and it makes proposals for legal policy. ${ }^{2}$ The English version, published in 2019, has been widely discussed and largely positively reviewed. ${ }^{3}$ This essay presents a decidedly critical

\footnotetext{
1 Katharina Pistor, The Code of Capital - How the Law Creates Wealth and Inequality (2019).

2 English Version of a German text, „Nationalreichtum und private Armut durch Zivilrecht? Eine Besprechung des Buchs „The Code of Capital “ von Katharina Pistor “, published in Rabels Zeitschrift, Mohr Siebeck, 85, 2021, pp. 854—875 with a reply by Katharina Pistor in the same Journal, ,Recht und Ökonomie im Spannungsfeld verschiedener Schulen “, pp.876-889.

3 Juvaria Jafri, Book Review: The Code of Capital: How the Law Creates Wealth and. Inequality by Katharina Pistor (26.9.2019), LSE Review of Books, < https://blogs.lse.ac.uk/ lsereviewof books/2019/09/26/book-review-the-code-of-capital-how-the-law-createswealth-and-inequality-by-katharina-pistor/ (28.4.2021); Massimiliano Vatiero, A Review of.

Katharina Pistor's „The Code of Capital: How the Law Creates Wealth and Inequality “

(15.1.2020), < https://www.law.ox.ac.uk/business-law-blog/blog/2020/01/review-katharinapistors-codecapital-how-law-creates-wealth-and > (28.4.2021).
}

Hans-Bernd Schäfer

hans-bernd.schaefer@law-school.de

1 Bucerius Law School, University of Hamburg, Harmburg, Germany 
perspective. It does not doubt important lines of thought in the book but questions several statements and hypotheses made in it.

\section{Lawyers of wealthy clients as engineers of legal development}

Predominantly, but not only in common law countries such as the USA and Great Britain, lawyers in the service of wealthy clients, legally codify their interests by developing new forms of law, and after having them confirmed by the courts, ultimately exploit the state's monopoly on the use of force to the benefit of their new coding. The outstanding importance of lawyers in the service of rich clients has a long historical tradition for the development of law, as shown by Pistor in a commendable fashion. Her quote from a speech by Lord Campbell in the House of Lords in 1851 can be viewed as the motto of the entire work. "There is an estate in the realm more powerful than either your Lordship or the other House of Parliament and that [is] the country solicitors" (p. 158). Lawyers made the English landed aristocracy ever richer by recoding - in Pistor's terms - property rights and ultimately succeeding in court. This insight contrasts the widespread view that law provides economic actors with a regulatory framework defining the "rules of the game"; a view widely upheld by representatives of the Freiburg School of Economics. ${ }^{4}$ In fact, according to Pistor, the wealthy or wealth-seeking individuals, with the help of resourceful lawyers, determine the rules of the game and continually change them in their favour. This contrasts with public choice theory, which emphasises the influence of powerful interest groups in the parliamentary legislative process, and which is both correspondingly sceptical of parliamentary law as well as seeing economic reason represented in the law of judges. ${ }^{5}$ Pistor shows the incompleteness of this theory and does not support Richard Posner's hypothesis of the welfare-economic superiority of private judicial law in relation to parliamentary law. Independent courts are faced with a very hard standing when rich families or large corporations finance lawyers, who are Masters of Legal recoding, and who can both successfully defend these recodings in all judicial instances and monopolise legal discussion.

Pistor's hypothesis is interesting and provides food for thought. However, it is insufficiently substantiated. Lawyers alone cannot recode legal norms that trigger changed competences over resources. Their proposals must be confirmed as legal norms by independent courts, else they lack the protection of the state's monopoly on the use of force.

\footnotetext{
${ }^{4}$ For a Survey see Matthias-W. Stoetzer, Die Ordnungspolitik Euckens als Theorie der Wirtschaftspolitik, (Economic order policy of Eucken as a Theory of Economic Policy “, Wirtschaftswissenschaftliches Studium 2001, 208.

5 Richard Posner, Economic Analysis of Law (1972); Paul H. Rubin, Why Is the Common. Law Efficient?, 6 The Journal of Legal Studies (JLS) 51-63 (1977); Richard Posner, The Ethical. and Political Basis of the Efficiency Norm in Common Law Adjudication, 8 Hofstra Law. Review 485-508 (1979); Paul H. Rubin, Common Law and Statute Law, 11 JLS 205-224. (1982).
} 
In this context, Pistor points to the internationalisation of law, which goes handin-hand with a decline in the importance of national courts and national legislation. Capital codifiers would only have to choose a country in which the courts accepted their recodifications with high certainty and subsequently apply them in other states (p. 160). The norms of private international law have certainly become more receptive of foreign law during the past decades. Consequently, foreign law becomes increasingly important in domestic legal practice. However, this can only explain a fraction of the undesirable developments alluded to by Pistor. First, the competition of legal norms triggered by these developments is often beneficial as it will drive out unsuccessful, inefficient or partial-interest-promoting national rules. Second, Pistor does not explain why foreign high courts defer to the suggestions of capital coders who only represent partial interests of their clients. After all, these states are not corrupt dictatorships, but highly developed constitutional states with independent courts. Thirdly, national law (or European law) continues to play a decisive role. Pistor would have to explain why independent courts follow coders when their proposals only generate wealth that benefits their clients and is detrimental to third parties. Finally, her hypothesis lacks analytical differentiation. For example, the Hague ruling which awarded compensation to Nigerian farmers for the pollution of their farmland caused by leaks in an oil pipeline owned by Shell, was only possible because of forum shopping. ${ }^{6}$ In Nigeria, the farmers would not have stood a chance of success. Forum shopping is not only a weapon of the powerful but can also be beneficial to the weak.

Pistor points out in some places that private arbitration tribunals are increasingly being used to resolve conflicts, the panels of which are appointed ad hoc by the parties and are therefore not independent (p. 180). Although their rulings are subject to public policy review by state courts, this would probably only prevent grossly erroneous developments. However, even if foreign law had already outgrown national law, which is not the case, the thesis of the power of the master coders remains unsubstantiated without a theory of judicial decision-making to support it. The reader is given the impression that private law in capitalist states is the self-made law of wealthy individuals and large corporations, which increases their wealth and fuels inequality.

Pistor should also have provided more evidence for her thesis because it contrasts the widespread theory that judicial law is superior to parliamentary law, since the former is less geared towards partial interests. Many authors in the US emphasise the independence and decentralised structure of state courts in this context. Pistor, for example, writes that the master coders create new law for their clients ("[they] often make new law", p. 160). She should also have elaborated why independent state courts, which—unlike parliaments—are relatively difficult to influence by

\footnotetext{
${ }^{6}$ Press release of the Court in the Hague on Farmers and Friends of the Earth v. Shell: Shell Nigeria Liable for Oil Spills in Nigeria (29.1.2021), <https://www.rechtspraak.nl/Organisatie-en-contact/Organ isatie/ Gerechtshoven/ Gerechtshof-Den-Haag/Nieuws/Paginas/Shell-Nigeria-liable-for-oil-spills-inNigeria.aspx > (28 April 2021). In 2015 the court had already given standing to the plaintiffs.
} 
interest groups, would in fact become the vicarious agents of lawyers who implement the interests of the rich and powerful through their rulings.

Literature does provide approaches to this extent. For example, in a treatise on the rise of the regulatory state since the end of the nineteenth century, Glaeser and Shleifer put forward similar theses and claimed that civil law had become detached from the interests of the public with the rise of "big business" since the end of the Civil War in the USA. ${ }^{7}$ This occurred because there was no longer equality of arms between the parties in a civil law dispute. In fact, political and civic engagement through parties, associations, and trade unions, as well as state democracy, regulatory law and mandatory parliamentary law have countervailed the undesirable developments, for example in labour relations, consumer protection and environmental protection. Another line of arguments in literature demonstrates that the likelihood of winning in a lawsuit depends on the effort that a party makes or can make in relation to the opposing party. If an imbalance does exist, higher courts are prone to become the plaything of the party that has the greatest incentive to spend a relatively large amount of resources on the underlying process by hiring the best available lawyers for the relatively highest number of billable hours. ${ }^{8}$

This aspect is somewhat diffused in Pistor's book. She argues that the right lawyers would be needed. The reasons why independent higher courts become vicarious agents and give legal force to the lawyers' legal recodings remain unclear. Is it a matter of class justice? Is it a dynamic that takes place behind the backs of the judges, who only get a view of the arguments of the lawyers of big companies whilst not perceiving the opposing party's view?

This is countered by the fact that not only paid stakeholders, but also independent academics shape legal discourse and influence case law. The development of civil law is the subject of debates in which legal scholars and academics from other disciplines participate alongside lawyers. Moreover, courts have an influence through their case law, whilst judges participate in the discussion through their own publications in journals, commentaries, and anthologies. These discussions are certainly not determined by the lawyers of large companies and their clients alone but encompass a spectrum of different and controversial argumentative households representing different interests.

\footnotetext{
7 Edward L. Glaeser /Andrei Shleifer, The Rise of the Regulatory State, 41 Journal of Economic Literature (JEL) 401-425 (2003). In this connection the decision Lochner v. New York of the US Supreme Court (1905) is often cited. It declared an occupational health and safety act as unconstitutional, as it cut into private autonomy of parties. It gave private autonomy a rank, which was not justifiable from a consequentialist perspective and was factually supporting employers' vested interests.

${ }^{8}$ Robert D. Cooter /Daniel L. Rubinfeld, Economic Analysis of Legal Disputes and Their Resolution, 27 JEL 1067-1097 (1989). The basic idea is that the probability of winning the case is a function of the plaintiff's and the defendant's investment efforts into the legal procedure. If there exist many similar cases for one side this creates incentives to spend more on lawyers than the other side, for which the gains from winning the case are comparatively small. Therefor the party with the higher stake will spend more on lawyers and thus increase the probability to win to a higher level, because the other side has less incentive to incur the same or higher costs for lawyers.
} 


\section{The coding of property}

To support her main thesis, Pistor draws on historical examples, such as the development of land ownership in England and the USA. In medieval England, large parts of agricultural land were either free land or the villagers' alms. Over time, members of the landed aristocracy fenced off the land, the infamous "enclosures", and used it exclusively for themselves, much like private property owners (pp. 31). This was an act of brutal violence which has been substantially investigated in the literature. However, as Pistor explains, it was accompanied by the activity of lawyers who carried out a recoding of land ownership rights and gradually shifted them towards the landed aristocracy, via court decisions, largely in the form of individual property as an absolute right. The traditional rights of use on the part of peasants were withdrawn without compensation in favour of the landed aristocracy in a long-lasting development. Subsequently, land ownership was further developed in favour of the landed aristocracy with the help of "trusts" and ownership was protected against creditors in favour of the noble families and their interest to keep the land in the family and protect it against black sheep within the family.

Pistor, however, broadly ignores the economic effects of this development, unlike e.g. Karl Marx, who in the first volume of "Das Kapital" devoted almost the entire chapter 24 on "primitive accumulation" to the above mentioned enclosures with multi-layered analysis thereof. ${ }^{9}$ Marx distinctly criticises such enclosures as a bloody act of violence but emphasises that they were a stage in the formation of capitalism and enabled "primitive accumulation" in England, which ultimately led to the industrialisation, which in turn resulted in both national wealth and private poverty. Other authors, such as North and Thomas' "The Rise of the Western World", emphasise that this development triggered a surge in land and labour productivity through increased arable farming, which enabled the generation of a large agricultural surplus beyond levels of self-consumption within the agricultural sector itself and hence could feed a rapidly growing urban population. ${ }^{10}$ These authors point out that countries such as Spain, in which the Crown was heavily dependent on the revenues of a "slaughter tax" and in which peasants' traditional rights to the land (commons) were protected and the land was prohibited from being converted into agricultural farm land, became relatively impoverished and that such countries were faced with an economic decline. With regard to England the economic historian Bairoch even speaks of an agrarian revolution that triggered the English urbanisation. ${ }^{11}$ Efficiency, the wealth of the nation or the development of the productive forces, which are central areas of economic analysis not only for Marx but in economics at large, play a very subordinate role in Pistor's book.

\footnotetext{
${ }_{9}$ Karl Marx, Das Kapital, Bd. I (1867) Kap. 24: Die sogenannte ursprüngliche Akkumulation (Ausgabe 1974) $741 \mathrm{ff}$. (The Capital, Vol.1, Ch. 24, The so called original accumulation).

10 Douglass C. North /Robert Paul Thomas, The Rise of the Western World: A New Economic History (1973).

${ }^{11}$ Paul Bairoch, Cities and Economic Development: From the Dawn of History to the Present (1988). According to Bairoch the enclosures played a decisive role for the modernization of agriculture and the increase of agricultural production in England.
} 
This must be viewed critically because the analysis of inequality through legal recodings of capital cannot be analysed in isolation from the productivity effects of such recodings. Legal recoding can cause great benefits for all, by eradicating poverty and yet greatly increase inequality, as is currently the case in China. It can increase national wealth and leave uncompensated damage as in the case of enclosures. And it can destructively cause pure redistribution in favour of the rich and to the detriment of the general public. This also results in a decline in productivity, as in the case of fideicommissa. If inequality is merely scrutinised in isolation, these cases cannot be differentiated because they all lead to an increase in statistical indicators of inequality such as the Gini coefficient. While Pistor (p. 222) emphasises that there is nothing wrong with efficiency-enhancing recodings if they do not have adverse effects on third parties, she does not incorporate this accurate insight into her illustrations. Such processes are not uncommon and can nevertheless greatly increase inequality. To some extent, China achieved this constellation, where wages in the modern sector rose parallel to national income whilst absolute poverty almost disappeared. Yet, income inequality has increased dramatically since the times of Mao Zedong. ${ }^{12}$

While enclosures led to the development of England's productive forces, the legal protection of noble families against their creditors through trusts and entailments described by Pistor was a backwards step in terms of institutional economics, as it precluded the use of land as a pledge for loans. To this extent the land became dead capital and led to an undercapitalisation of noble estates throughout Europe. The physiocrats Jacques Turgot and François Quesnay clairvoyantly analysed this in the eighteenth century as a root cause for the backwardness of French agriculture. ${ }^{13}$ Such essential differentiations are omitted in Pistor's book because she only focusses on the negative third-party effects of legal recodifications and the impact on income inequality. Pistor mentions the example of the "Silesian Landscapes" (p. 93). After the Seven Years' War, the Prussian King Frederick II allowed both the Silesian nobles to pledge their estates and their creditors to securitise the claims, which resulted in a rapid reconstruction of that war-ravaged province.

Moreover, the commercial pressure towards legal recodification has often not tended towards an asset shield. Instead, debtors were not protected from creditors, which could bear detrimental economic effects, but rather assets were encoded as collateral for loans in order to mobilise credits for businesses. In Germany this applies, for example, to security property, that is the division of property functions into security functions and functions of use, with fiduciary ties on the part of the security owner. The discussions about the admissibility of the retention of title as a circumvention of the right of lien was affirmed by the German Imperial

\footnotetext{
12 The Gini-coefficient in China increased during the first decade of the 20first century from much below 0,3 to more than 0.45; Martin King Whyte, China's Post-Socialist Inequality, 111, Current History 229234 (2012).

13 Hans-Bernd Schäfer, Landwirtschaftliche Akkumulationslasten und industrielle Entwicklung: Analyse und Beschreibung entwicklungspolitischer Optionen in dualistischen Wirtschaften (1983) Ch. 4; (The burden of agriculture for industrial development, Analysis and description of development options in dualistic economies).
} 
Court as early as 1899. Since the disputes at the Legal Colloquia (Juristentag) of 1908 and 1914, this economically productive solution has no longer been seriously questioned.

Hardly any problem of civil law in Germany has been discussed as thoroughly as this one, not least with regard to its legal dogmatic classification. Ultimately, economic considerations have led to a consolidation of the legal classification of the conditional sale and to an expansion of its cases of application (extended retention of title, retention of current account, downstream retention of title, forwarded retention of title). As a result, after the Second World War, any current assets owned by a German company, including the last receivable and even petty cash, were mobilised for credit security purposes. This not only increased profits, but also contributed to a rapid economic reconstruction. The so-called transferring reconstruction in bankruptcy proceedings is also the fruit of the advocacy activity so criticised by Pistor. In fact, it legally raised the efficiency of the failed old German bankruptcy code and created better possibilities to save viable companies from being broken up.

By presenting numerous legal historic examples, Pistor erroneously concludes that since coders only pursue the interests of their profit-oriented clients, this would be sufficient for a critique of legal policy. This falls behind essential insights obtained in political and economic science, ranging from Niccolò Machiavelli ${ }^{14}$ via Adam Smith to Karl Marx and contemporary economics. Marx, in particular, held that the development of productive forces and economic progress were linked to the assertion of a class interest, which under certain conditions was productive or counterproductive for national wealth. When Pistor writes about wealth via the recoding of legal norms, she does not distinguish clearly enough between (1) wealth in a patronage economy, which can only be established via redistribution and by making society as a whole stagnant or poorer, (2) increased wealth from institutions, that advance a country economically but can be detrimental by not compensating the losers from institutional changes, and (3) increased wealth without losers, which is beneficial to society at large, but at the same time increases inequality.

A disinterest in the allocative consequences of law can also be observed in Pistor's description of the land grabbing by white settlers in North America. The settlers paid little regard to the traditional forms of ownership of the indigenous population. The land was transformed via brutal force and by means of legal recoding by lawyers and courts into private property of the white settlers, i.e. a withdrawal from the disposal of the indigenous population. However, what would have happened if the legal system had protected the traditional property rights of the indigenous tribes through the seniority principle, as Pistor demands (p. 34)? Before the settlement of North America by the whites, a study by Denevan ${ }^{15}$ shows that this territory with its indigenous agricultural output fed and housed about 3.8 million indigenous people

\footnotetext{
14 Machiavelli urged the Prince of Medici to unite Italy: ,for his own fame and the welfare of the whole Italian people"; Niccolò Machiavelli, Der Fürst (The Prince) (1513), cited after the German edition of $1963,106$.

15 William M. Denevan, The Pristine Myth: The Landscape of the Americas in 1492, 82, Annals of the Association of American Geographers 369-385 (1992).
} 
on an area of almost 20 million square kilometres (more than 7 times the territory of the EU 27). Pistor vividly describes how traditional rights were disregarded but does not present an alternative to brutal subjugation that would have been compatible with immigration and settlement, and which would have considered the difficulty of constructing a legal transaction for the transfer of traditional, inaccurately defined and idiosyncratic property rights with multiple veto positions among families, clans and tribal heads.

Disinterest in the productive properties of civil law norms can also be seen in Pistor's analysis of the codification of legal persons, which has been promoted by lawyers since the Middle Ages. Their only aim was to provide an asset shield for their clients (p. 57). The self-serving motive of this codification was to protect the assets that merchants brought into a company and thus the existence of the company from the access of the shareholders' creditors and much later, in the context of a "limited company", to enable private assets to be separated from company assets. Here Pistor ignored the fact that in these codings, unlike the failure to respect indigenous property rights in North America or the exclusion of peasants from common land in England, the recoding is not usually associated with negative third-party effects. After all, a lender who can no longer access his debtor's company assets, but only company shares, will react with a higher interest margin to price in terms of credit default risk, or will not grant the loan. The same applies to the principle of limited liability. Corporate loans are thus made more expensive or only granted against collateral. Negative third-party effects usually do not occur at all-with the exception of forced creditors (especially accident victims). ${ }^{16}$ Moreover, as suggested but not elaborated by Pistor, the gradual development of the legal person is one of the most productive legal innovations in European legal history, which-as Timur Kuran has shown-has significantly promoted the rise of Western Europe as the economic powerhouse of the world since the thirteenth century. ${ }^{17}$ For only it enabled companies with a long lifespan, whose individual assets were secured within the company and independently of the financial situation of their shareholders, to securitise and trade its shares on stock exchanges. It facilitated the conversion of long-term assets into liquid assets and the pooling of capital from many investors. This in turn facilitated the emergence of large companies who were able to realise economies of scale. This new legal form hardly produced any losers. Nevertheless, it only ever created enormous wealth where it was first applied, which of course increases inequality. This cannot be equated with the inequality that creates private wealth in a patronage economy at the expense of all and with declining levels of national wealth. One can agree with Pistor when she writes that the coding of capital is the key to the distribution of wealth in a society (p. 222). But it is important to differentiate whether the coding either fuels the redistribution of wealth at the expense of others and even of national wealth or whether it increases productivity.

\footnotetext{
${ }^{16}$ For an overview see Hans-Bernd Schäfer /Claus Ott, The Economic Analysis of Civil Law, $2^{\text {nd }}$ edition, 2021. Chapter 25.

17 Timur Kuran, The Long Divergence: How Islamic Law Held Back the Middle East (2011), pp.60.
} 
The fact that legal norms can play a prominent role in economic development, in both a positive and negative sense, has become common knowledge today. ${ }^{18}$

\section{Coding of capital and tendency towards more inequality?}

The coding of capital by lawyers follows-according to Pistor-the logic of power and money. This can hardly be negated. However, to conclude that this leads to inequality or even impoverishment is a big step that requires more careful analysis than in Pistor's book. In general, profit-maximising is not bad per se. It is not clearly negatively aligned with the demands of social ethics. The same applies to altruistic behaviour, which can degenerate into paternalism. For a social-ethical critique of egotistic behaviour, special conditions must be met and deliberated. The current financial crises, the worldwide increase in inequality and the stagnation of real wages since the 1980s, especially in the USA, are certainly cause for concern. But Pistor describes an economic and legal system that evolved over centuries, took hold in Western countries at the turn of the nineteenth century, and led to an unprecedented increase in mass prosperity and general welfare, including better health, schooling, and higher life expectancy. No competing economic system has ever come close to achieving this. A comprehensive economic history study by Jan Luiten van Zanden and others in 2014 proves this. ${ }^{19}$ Between the year 1820 and 2000, average real wages of construction workers in Western Europe increased

\footnotetext{
18 Robert E. Hall /Charles I. Jones, Why Do Some Countries Produce So Much More Output per Worker than Others, 114 Quarterly Journal of Economics 83-116 (1999); Dani Rodrik /Arvind Subramanian / Francesco Trebbi, Institutions Rule: The Primacy of Institutions over Geography and Integration in Economic Development, 9 Journal of Economic Growth 131-165 (2004); Dani Rodrik, Goodbye Washington Consensus, Hello Washington Confusion? - A Review of The World Bank's „Economic Growth in the 1990s: Learning from a Decade of Reform “, 44 JEL 973-987 (2006). These authors highlight that without enforcement of contracts and protection of property and investments economic development is not possible. Hall / Jones (this footnote) summarize the result of their comprehensive empirical study: „Countries with corrupt government officials, severe impediments to trade, poor contract enforcement, and government interference in production will be unable to achieve levels of output per worker anywhere near the norms of Western Europe, Northern America, and Eastern Asia ". (86). Rodrik (this footnote) stresses that to achieve this a rule of law state in the western sense is not a necessary condition but can also be realized by substitute institutions, as merchant guilds or powerful intermediaries of the state or a political party. „The cross-national literature has been unable to establish a strong causal link between any particular design feature of institutions and economic growth. We.

know that growth happens when investors feel secure, but we have no idea what specific institutional blueprints will make them feel more secure in a given context. The literature gives.

us no hint as to what the right levers are. Institutional function does not uniquely determine.

institutional form " (979). This view is today shared in most of the literature. However, there exist no rich countries -with the exception of some countries rich with raw materials- which did not achieve the rule of law.

Robert D. Cooter/Hans-Bernd Schäfer, Solomon's Knot: How Law Can End the Poverty of Nations (2013).

19 How Was Life? - Global Well-Being Since 1820, hrsg. von Jan Luiten van Zanden/

Joerg Baten/Marco Mira d'Ercole /Auke Rijpma /Conal Smith/Marcel Timmer (2014), Pim de Zwart / Bas van Leeuwen / Jieli van Leeuwen-Li, Real Wages Since 1820, in:

van Zanden et al. (Fn. 20) 73-86.
} 
13-fold and real per capita income increased 16-fold. The USA, Canada, Australia, and New Zealand are often grouped together in economic history time series as "western offshoots". ${ }^{20}$ In this group of countries, real per capita income increased 21-fold from 1820 to $2000 .{ }^{21}$ Estimates of the real wages of construction workers are only available for the period from 1860. By 2000, they had increased 3.8-fold since 1860. In the US, real per capita income increased 21-fold from 1820 to 2000. For real wages in the USA, the above-mentioned study only contains time series from 1920 to 2000 . During this period, real wages of construction workers increased by a factor of $2.9 .^{22}$ In every strata of the population, life expectancy and educational attainment have increased dramatically since then. Similar figures apply to the USA, Canada or Australia, but by no means to those countries that were less capitalist than the ones mentioned. Such findings are incompatible with the description of a legal system that essentially consist of making the rich richer and the poor poorer. It is fair to say that scientific progress and access to the medical system provides a contemporary welfare recipient in Western Europe with better health than wealthy people could achieve in the eighteenth century. This achievement is to a great extent the result of the welfare state in combination with market forces and related patent protection.

There is also no evidence that inequality systematically increases in market capitalist systems, which Pistor claims. Figure 1 contains a time series of the Gini coefficient for Western Europe and the USA. The Gini coefficient, a number between zero and 1 (or expressed as a percentage between zero and 100), is the most common statistical measure of inequality of income and wealth. A Gini coefficient of zero implies that all income earners have the same income; a Gini coefficient of 1 implies that all national income is accounted for by one individual. The empirically determined Gini coefficient thus indicates the deviation (in terms of percentage points) of the factual income distribution from an equal distribution.

The study by Moatsos and others ${ }^{23}$ shows that income inequality in Western market economies, expressed by the Gini coefficient, has increased since 1980 and that in the USA the inequality estimated in this way was greater than in Western Europe in 9 of the 12 investigated years of the time series. ${ }^{24}$ However, it does not provide evidence for the claim that market economies tend to increase inequality.

The finding is reinforced by a time series of the World Inequality Database, which expresses the sum of the incomes of half of the lowest income earners as a

\footnotetext{
${ }^{20}$ Maddison introduced this term in his seminal empirical studies of time economic history time series data. Angus Maddison, The World Economy, Vol. I: A Millennial Perspective, und Vol. II: Historical Statistics (both in the 2006 edition).

21 See Jutta Bolt /Marcel Timmer / Jan Luiten van Zanden, GDP Per Capita Since 1820, in: van Zanden et al. (Fn. 20) 57-72.

22 Figures are based on own calculations on the basis of data in the study of Jan Luiten van Zanden et al. (see Fn. 20) Compare especially Table 3.2. on p. 65, Table 3.4. on p. 67, Table 4.4. on p.80 and Table 4.6 on p. 81.

23 Figures are from Michail Moatsos / Joerg Baten /Peter Foldvari /Bas van Leeuwen / Jan Luiten van Zanden, Income Inequality Since 1820, in: van Zanden et al. (Fn. 20) 199-215, 206, 210 .

24 Source: World Inequality Database, < https://wid.world/ > (22.1.2021).
} 


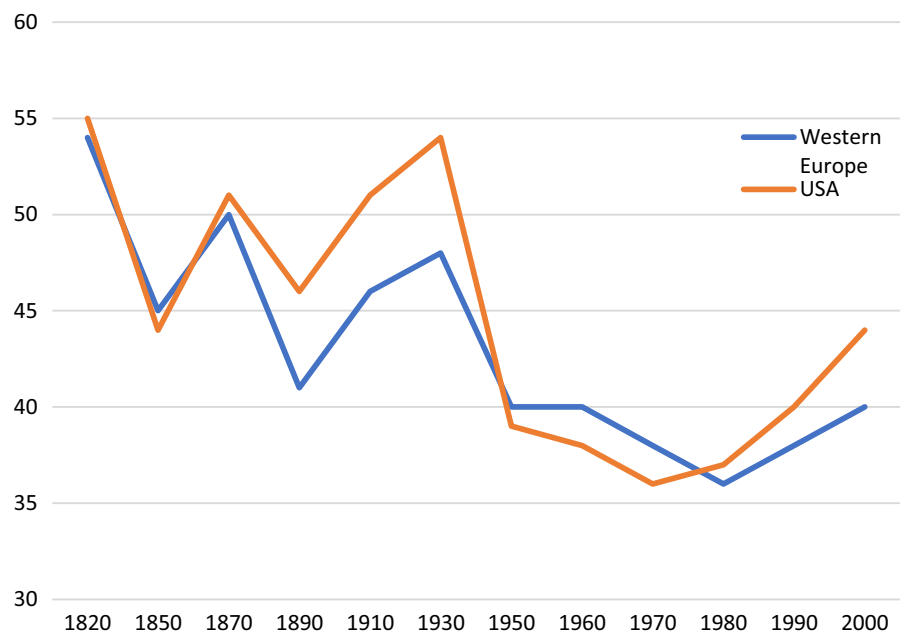

Fig. 1 Income inequality in Western Europe and the USA, 1820-2000, development of the Gini coefficient (in per cent)

percentage of all incomes and, unlike van Zanden's study, contains data up to 2019. Long time series going back to the 1920s exist in this study only for the USA and France and are included in Fig. 2.

The long-term series of this inequality indicator available for France and the USA also show no long-term increase in inequality. For France, the overall trend line is rather indicative of a long-term decrease in inequality. Until 1980, inequality in the USA trended downwards, after which it increased-as in France-but more sharply than in France and most western industrialised countries. The same study shows that income inequality, as defined in Fig. 2, decreased slightly for the most part in Western industrialised countries between 2010 and 2019, and that the trend of increasing inequality since 1980 did not continue in the second decade of the twenty-first century. There is no evidence of a trend-like permanent increase in inequality in the Western capitalist system. This finding is not contradicted by the fact that more than three decades of rising income inequality after 1980 and even stagnating real wages in the USA have destroyed the confidence that the market economy always brings rising prosperity for all.

Income inequality (and even more so wealth inequality) has always been much higher in capitalist systems than in socialist systems, all of which had Gini coefficients of just over 20. They rose consistently from just over 20 to over 30 in the former CMEA states after the end of the Soviet Union, ${ }^{25}$ whilst China's coefficient rose to $45 .^{26}$ Inequality, however, is partly an epiphenomenon of economic freedom.

\footnotetext{
25 Branko Milanovic, Explaining the Increase in Inequality During the Transition, The Economics of Transition 7 (1999) 299-341.

${ }^{26}$ Statista (2021) Gini Coefficient in China, < https://www.statista.com/statistics/250400/inequality-ofincome-distribution-in-china-based-on-the-gini-index/>(11.1.2021).
} 


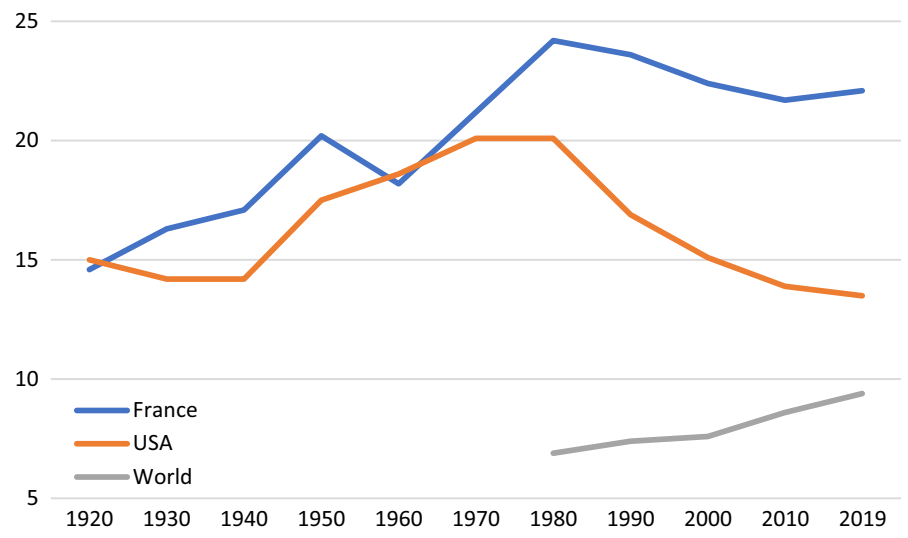

Fig. 2 Share of the 50 per cent of lowest income earners in France and the USA 1920-2019

It would arise even if the use of economic freedom could not cause negative thirdparty effects. If one only looks at inequality as a consequence of profit-maximisation in a liberal system, one can no longer distinguish between an innovator like Guglielmo Marconi, who invented and successfully marketed wireless telegraphy and radio, as opposed to the English aristocrats who took land from the peasants but triggered agricultural development, or a mafia-like oligarchy that uses legal norms to keep a society underdeveloped but becomes rich itself. All three phenomena will raise the Gini coefficient. It is inconceivable that Katharina Pistor is unaware of these differences. Her book consists of a string of historical examples, each of which falls into one of these categories, from the enclosures in England, via the wealth-destroying asset shield of aristocratic families, to the asset shield of the legal person. The latter comprises one of the greatest and economically most powerful innovations in the history of law. To lump all this into one category is an analytical mistake.

It is clear and indisputable that income inequality in Western free-market economies has increased sharply since 1980 and into the second decade of the twentyfirst century. In the USA, this was even associated with a stagnation of real wages. It would therefore have been sensible to focus the analysis on this period and to describe the causal factors thereof. The author would then most likely not have attributed all this to the master coders who have been at work for centuries. A monograph aimed at a broad audience certainly cannot be expected to filter out these factors and the strength of their influence using statistical econometric methods. But references to other causal factors for the increase in inequality since $1980{ }^{27}$ would have been appropriate. These include inadequate schooling and more difficult access to institutions of higher learning. They also include the disappearance of industrial

\footnotetext{
27 World Inequality Report 2018, Editors: von Facundo Alvaredo/Lucas Chancel /Thomas Piketty / Emmanuel Saez /Gabriel Zucman (2018); see also Kaushik Basu, Globalization, Poverty and Inequality: What Is the Relationship? What Can Be Done?, in: The Impact of Globalization on the World's Poor, edited by Machiko Nissanke /Erik Thorbecke (2007) 300-318.
} 
production in many Western countries after most developing countries ended their nationalist (import-substituting) economic policies in the 1980s and began production for the world market, which reduced the income opportunities of poorly educated workers in rich countries. And it would include the rise of the IT industry, which pays well educated workers very well and does not need others. Finally, too little state investment in public goods also plays a role. As an important factor, the internationalisation of law can also be part of this. Private international law, which contains the adjusting screws for the degree of internationalisation of law, was still a matter for specialists in divorce law a few decades ago. In the meantime, it has become a central legal matter that strongly shapes our lives. Pistor should be credited for emphasising this point.

\section{Ownership of personal data}

Against the background of historical developments, Pistor makes a connection to the internet giants who have tremendously profited from the processing of personal data. They do not have copyright on the raw personal data they collect, but are usually protected by trade secrecy (pp. 126-127). Coupled with effective encryption technologies, these companies have not de jure but de facto exclusive ownership of the raw data of internet users. Indeed, this situation raises significant legal policy issues within the realm of intellectual property law, competition law and personal data ownership. Internet companies place their own products in privileged places. They generate new data sets using algorithms that have market value unlike the raw data. But they do not have to share their raw data with competing companies that could also generate and market new and valuable datasets from the same raw data. Scientists do not have secure access. Protecting the raw data as trade secrets prevents employees who start their own business or move to other companies from taking data with them, which hinders competition and is criticised by Pistor with good reason.

The fact that personal data is de facto owned by internet companies and that the corresponding legal codifications of raw data have been willingly implemented by courts in the US and elsewhere, is compared by Pistor with the English feudal lords' violent seizure of land through "enclosures" ("We are now in danger of losing access to our own data"). Pistor describes this as "the second enclosure" (p. 131). This is inadmissible not least because of the recognition of trade secrets and the emergence of de facto ownership of raw data by internet giants has not led to a destruction of livelihoods or the loss of lives, but also provides a quid pro quo through the gratuitous use of social media. Moreover, comprehensive ownership under civil law of all information about one's own person cannot be derived solely from reasons of personality protection and the protection of human dignity, and certainly not from a natural right ("our own data"). In its census ruling, the German Federal Constitutional Court already rejected the idea of a quasi-natural right to personal data with sound arguments and drew a legally and economically convincing dividing line between 
the protection of property and the protection of personality. "The individual does not have a right in the sense of an absolute, unrestricted dominion over 'its data'. ${ }^{28}$

Who am I, where and how do I live? The answers to these questions are secrets worthy of protection, which. All constitutional states provide this even though debatable differences exist. Further-reaching rights that would apply to any use of personal data, even if they remain anonymised in newly created data sets, cannot be justified on the grounds of data protection, and must face an economic or social test of expediency.

Such tests quickly trigger justification difficulties. At the very outset, a central problem is the clarification of terms. Ownership of personal data that goes beyond data protection is difficult to define and enforce. Absolute rights, unlike relative rights such as bilateral contractual rights, must not be idiosyncratically drafted, as they are protected against everyone and impose obligations on everyone. They must therefore be easily recognisable in order to be upheld. ${ }^{29}$ This alone restricts an extension of property-like rights to data beyond data protection. Such restrictions do not exist in small tribal societies where complex absolute rights are indeed common. For there is an inverse relation between the complexity of a society and the complexity of property rights in the sense of absolute rights. Property in globalised societies endows a large and incalculable number of people with rights and imposes duties on an even much larger number of people. Therefore, an absolute right must then be easily recognisable and, if possible, protected by a simple "hands off" rule.

If individuals had an absolute right to "their" data, they would be able to sell their personal data to information intermediaries. This leads to high transaction costs. Each time a contract is concluded, an additional agreement would have to be reached on the prices of the data transferred. The question then arises whether such a market with billions of data owners can come about easily (or at all) and whether such ownership of data is therefore economically expedient. In addition, fragmented ownership of data enables strategic behaviour, hinders data sharing and thus raises anti-commons issues that would also contribute to an under-use of data. ${ }^{30}$

Even if one disagrees with Pistor on this point: she highlights a major legal problem whose current solution favours monopoly positions of internet companies. A digital divide exists between those with and without access to Big Data. Scientific users can be excluded from access to the data at will. To prevent a new division between insiders and outsiders, the law would have to facilitate access to this data. But those who legally recoded the big data sets in the interest of their clients have no interest in this.

\footnotetext{
28 BVerfG 15 December1983 - 1 BvR 209/83 u. a., BVerfGE 65, 1, 43 f.; Compare also Hans-Peter Bull, Wieviel sind ,meine Daten “ wert? (How much are "my data” worth?), Computer und Recht 2018, 425432.

29 Henry E. Smith, Standardization in Property Law, in: Research Handbook on the Economics of Property Law, edited by Kenneth Ayotte /Henry E. Smith (2011) 148-17.

30 Nestor Duch-Brown /Bertin Martens /Frank Mueller-Langer, The Economics of Ownership, Access and Trade in Digital Data, JRC Digital Economy Working Paper, Nr. 2017-01, esp. 29-30; Alessandro Acquisti /Curtis Taylor /Liad Wagman, The Economics of Privacy, 54 JEL 442-492 (2016).
} 
Pistor's comments on patent and copyright law, whose level and duration of protection she considers excessive and in part counterproductive and which, as a result of multiple veto positions, often hinder rather than promote the emergence of new knowledge, are accurate and in line with an emerging consensus in legal economic research (p. 118). These rights are still being extended rather than restricted, creating wealth among a few at the expense of national wealth. It is noteworthy that Pistor uses consequentialist utilitarian arguments to arrive at this view on patent and copyright protection. However, when she writes about a right over personal data even when this right goes beyond what is required for the protection of personality and human dignity, she argues non-consequentialist (our own data). This change of perspective is neither explained nor made explicit.

\section{The coding of credits}

Credit securitisation, money creation, fiat money and options, whose inventors Pistor compares to alchemists, are covered extensively in the book. Pistor rightly rejects considering capital as physical entities. But even with complex financial products, their relationship with the goods of the real economy remains, and the productivity and value of the latter are in turn influenced by the legal coding of financial products. One cannot argue that only the legal coding turns real goods into capital, as Pistor suggests. In many countries, lawlessness prevails even today: property only exists in the form of de facto dominion over physical objects or in private knowledge, i.e., goods that can be defended against a corrupt and kleptocratic state or against predatory gangs. Nevertheless, these goods are utilized for production and consumption, albeit at low levels. Legal coding increases the productivity of physical goods and of private information but does not lead to its generation. The comparison with alchemy is problematic. In institutional economics, the term "effective commodity" has been coined for the combination of things with property rights. This also applies to the securitisation of credit contracts between creditor and debtor through bearer instruments such as bills of exchange or bonds. This does not create new capital but increases the real value of the underlying claims for creditors. Mortgage loans are initially non-transferable or difficult to transfer. By recoding them into liquid and fungible assets, they can be traded globally, and capital goods can be mobilised for the production of beneficial real estate around the world. The properties of additional transferability and liquidity generated via legal norms increase the value of the claim for the creditor without the debtor losing anything and mobilise capital. But in the end, there is only the original credit contract with its risks that enabled the acquisition of a thing.

Pistor's portrayal of the Lehman crisis with its worldwide repercussions through an "institutional autopsy" (p. 48) of the Lehman Group is flawed insofar, as she identifies as primary causes of the crisis, the increasingly complex coding of mortgage loans through ever longer and more confusing corporate nesting, securitisation, and coding chains. While the complicated securitisation of mortgage loans was a conditio sine qua non for the Lehman crisis, it contributes little to its understanding. An analysis that focuses on this point leaves in the dark why many banks, especially 
in Europe, got soaked into these financial products until they finally had to be rescued by the state. It can be ruled out that the banks were uninformed, or unaware that at the end of the financial chain there were only subprime loans, or in fact that they were misled by master coders. It is also impossible that they blindly trusted the triple-A ratings of the rating agencies. This crisis can neither be explained with asymmetrical information between securitisation firms and banks similar to market failure in the business to consumer relation. Nor did it begin with exploitative goals, but rather with the social policy efforts of the Clinton administration to enable every American to buy their own home with mortgage loans. ${ }^{31}$ The Housing and Community Development Act of 1992, passed under the Clinton administration, was designed to help disadvantaged groups and minorities to achieve home ownership. ${ }^{32}$ President Bush continued this policy. The loans were to cover the full purchase price of the property, require no equity on the part of the buyer, and also limit the recovery of the debt to the value of the property in the event of non-servicing. The US government encouraged mortgage banks to market these subprime loans aggressively (reverse redlining). This is social policy strategy in a country whose parliament is permanently opposed to establish a welfare state financed by progressive income taxes and levies. Every bank that spent billions was aware of this. Why then were so many such claims bought in securitised and money-like form from banks outside the US, including the proverbial "stupid German money"? The US Federal Reserve supported the expansion of mortgage lending with an "easy money policy" that created property price inflation such that mortgage lenders who had financed 100 per cent of the purchase price of the property were able to sell the property at an inflated price if borrowers defected or failed to service their loans. The plan was to let this asset inflation run out with a soft landing via the central bank's monetary policy. These securitisations would ultimately have generated a win-win constellation in which (almost) all Americans would have emerged as homeowners and many banks along with their depositors of time deposits around the globe would have profited. Many believed in this bet; the very low equity ratio of countless financial institutions fuelled the risk appetite beyond healthy levels and systemically important financial institutions, which were too big to fail probably also hoped to be bailed out in a worst case scenario. Otherwise, the toxic papers would not have found buyers at hundreds of banks around the globe. Things turned out differently, and when real estate prices in the USA fell sharply, the crisis unfolded. If the legal codifications of subprime loans are identified as relevant reason for the crisis, this does not lead to a its comprehensive understanding. The securitisation of risky mortgage loans and the mixing with less risky loans in this securitisation process were necessary but not sufficient conditions for triggering the catastrophe. Katharina Pistor shall be reminded of the fact that the Greek and Euro crises that emerged in the wake of the

\footnotetext{
31 I owe this information to Thilo Kuntz from Bucerius Law School in Hamburg.

32 See Board of Governors of the Federal Reserve System (US): Effective Federal Funds Rate, $<$ https:// fred.stlouisfed.org/series/FEDFUNDS $>$, Bank Prime Loan Rate, $<$ https://fred.stlouisfed.org/series/ DPRIME $>$, Delinquency Rate on Consumer Loans,

All Commercial Banks, < https://fred.stlouisfed.org/series/DRCLACBS > (alle 25.6.2021).
} 
Lehman crisis had a similar cause. Banks with low levels of risk capital were incentivised to assume risk by buying Greek government bonds, even though these were simple-coded, "plain vanilla" bonds. Consequently, the Nobel Prize winner Kenneth Arrow arrived at a completely different assessment of the financial crises in the last decade. ${ }^{33}$ If one sees the legal codifications of sub-prime loans as a relevant cause of the crisis, one does not arrive at a comprehensive understanding. As every lawyer knows, knowledge of necessary conditions often hinders rather than facilitate the understanding and legal-political classification of an event. It was not the securitisation and mixing of mortgage loans of varying quality, but more decisively, the belief in prolonged asset inflation coupled with the undercapitalisation of financial institutions in Western countries. Martin Hellwig and Anat Admati arrive at a similar assessment and consequently demand for increased equity capital ratios for banks. ${ }^{34}$

\section{Policy recommendations}

In her legal policy recommendations, the author limits herself to instruments of civil law. It is obvious that many of the negative effects of civil law recodings described in Pistor's book can be eliminated via welfare state norms and transfers to the disadvantaged and via tax law to the extent that they increase national wealth. Regulatory law can prevent them if they only redistribute in favour of the rich while decreasing national wealth. This is largely ignored in the book, which focuses on civil law. Yet, it would have significantly complemented the overall picture. When Pistor calls for the general abolition of civil law recodifications of capital by lawyers and courts that exceed the basic modules (p. 224), she overshoots the underlying goal and gives the impression of a tunnel view. For many of the recodifications described by Pistor simultaneously increase national wealth and cause disadvantages to third parties, which can be compensated via social law. Often, they are productivity-enhancing without causing harm to third parties, yet they increase income inequality. This can be counteracted by a differentiated legal system, in which civil law provides efficient solutions that promote national wealth whilst social law provides equitable solutions. This has been the formula for success in taming an unbounded market economy since Bismarck's social legislation, which dozens of countries imitated. It is also a formula shared by the vast majority of economists. Pistor's call to ban civil law innovations beyond

\footnotetext{
33, ,[...] given the incentives, the agents were behaving rationally. The root of the matter. is that liabilities are limited from below. A firm can go bankrupt, but that is the worst that can. happen to it. Similarly, an executive of a company can at worst be dismissed. The extra bonuses compensating him or her for performance in the event that things went well are not paid.

back in bad times. As a result, a risky investment that is socially unprofitable (a negative expected value or a positive expected value insufficient to compensate for the market-determined risk level) may be privately rational for the decision-maker, because the latter will not bear all the negative consequences "; Kenneth Joseph Arrow, Economic Theory and the Financial Crisis, Information System Frontiers 14 (2012) 967-970.

34 Martin Hellwig /Anat Admati, The Bankers' New Clothes: What's Wrong with Banking and What to Do About it (2013).
} 
the "basic code" omits the insight that goals of social justice in a market economy are largely better served, with a significantly lower macroeconomic loss, by means of state transfer payments and tax law, than by simply prohibiting new and productive legal institutions. This insight has not been accepted worldwide, but it has prevailed at the level of most Western economies and also throughout Europe. After the introduction of the Deutschmark and the German reunification, East Germany was suddenly exposed to the effects of globalisation. Two trillion euros in transfer payments have flown into the new federal states during the past 30 years, primarily in the form of social transfers. ${ }^{35}$ In the realm of globalisation, this is not exactly proof of an inability to act on the part of a welfare state oriented towards a national market economy. When Portugal and Spain entered the EU, it was clear that their highly protected industries would collapse. To compensate, they received payments from the European Structural Fund, which has since developed into an important element of EU policy. ${ }^{36}$ During the current Corona crisis, transfer payments from the EU to member states have reached staggering dimensions: 750 billion euros in the form of a reconstruction plan, 390 billion euros of which are transfers. ${ }^{37}$ The rest are cheap loans. Under the SURE instrument, the EU spends up to 100 billion euros to secure jobs and prevent dismissals. EU member states can borrow a further 240 billion euros, some of it at reduced interest rates, from the European Stability Mechanism (ESM) for corona-related healthcare expenditure.

However, one can agree with Pistor on other proposals presented (p. $224 \mathrm{ff}$.). The globalisation of law through forum shopping and the expansion of extraterritorial law is partly correctly criticised by her. However, she omits the fact that this can also comprise a weapon of the weak in countries without the rule of law. Pistor rightly criticises the increasing replacement of independent state courts by politicised arbitration tribunals staffed by the parties, especially in the protection of international investments. The proposal for an extension of civil liability for those disadvantaged by recodification in the context of increased use of class action is also welcome, alongside her plea for a long-term and incremental approach.

The book contains empirical inaccuracies and analytical weaknesses, and its legal policy recommendations are too narrowly focused on civil law. However, it proves an important central thesis: private law "coded" by lawyers in the service of large corporations and which is accepted by courts, coupled with the international competition of legal norms in a globalised world, does not necessarily lead to a market economy with prosperity for all without countervailing forces. The book also shows that for these actors, civil law is not a regulatory framework

\footnotetext{
35 Michael C. Burda, 30 Jahre deutsche Einheit: Wie steht es wirklich? (30 years of German unification, how is.

the reality?) Wirtschaftsdienst 2020, 390-391.

36 Peter Becker, Die europäische Kohäsionspolitik und die Strukturfonds (The European politics of cohesion and the structural funds), in: Handbuch Europäische Union, edited by Peter Becker/Barbara Lippert (2020) 860-885.

37 < https://ec.europa.eu/info/strategy/recovery-plan-europe_de>(29.4.2021) and < https://ec.europa.eu/ info/strategy/recovery-plan-europe_de > (29.4.2021).
} 
but an instrument that is constantly being developed and reshaped through selfinterest, with independent courts having to agree such that ultimately the recodifications can be enforced with the state's monopoly on the use of force. Finally, the book rejects the thesis of a fundamental legal-political superiority of private ordering over public choice. These are important contributions of the book, for which the author deserves recognition.

Funding Open Access funding enabled and organized by Projekt DEAL. Hans-Bernd Schäfer declares that he received no funding for this paper.

\section{Declarations}

Conflict of interest Hans-Bernd Schäfer declares that he has no conflict of interest.

Open Access This article is licensed under a Creative Commons Attribution 4.0 International License, which permits use, sharing, adaptation, distribution and reproduction in any medium or format, as long as you give appropriate credit to the original author(s) and the source, provide a link to the Creative Commons licence, and indicate if changes were made. The images or other third party material in this article are included in the article's Creative Commons licence, unless indicated otherwise in a credit line to the material. If material is not included in the article's Creative Commons licence and your intended use is not permitted by statutory regulation or exceeds the permitted use, you will need to obtain permission directly from the copyright holder. To view a copy of this licence, visit http://creativecommons.org/licen ses/by/4.0/.

Publisher's Note Springer Nature remains neutral with regard to jurisdictional claims in published maps and institutional affiliations. 